\title{
Assessment of Land Use Land Cover Change Drivers and Its Impacts on above Ground Biomass and Regenerations of Woody Plants: A Case Study at Dire Dawa Administration, Ethiopia
}

\author{
Amisalu Milkias*, Tessema Toru \\ College of Agriculture and Environmental Sciences, Haramaya University, Haramaya, Ethiopia \\ Email: *amsemilke@gmail.com
}

How to cite this paper: Milkias, A. and Toru, T. (2018) Assessment of Land Use Land Cover Change Drivers and Its Impacts on above Ground Biomass and Regenerations of Woody Plants: A Case Study at Dire Dawa Administration, Ethiopia. Atmospheric and Climate Sciences, 8, 111-120.

https://doi.org/10.4236/acs.2018.81008

Received: September 30, 2017

Accepted: January 23, 2018

Published: January 26, 2018

Copyright $\odot 2018$ by authors and Scientific Research Publishing Inc. This work is licensed under the Creative Commons Attribution International License (CC BY 4.0).

http://creativecommons.org/licenses/by/4.0/

(c) $\underset{\mathrm{EY}}{\mathrm{C}}$ Open Access

\begin{abstract}
Understanding land use land cover (LULC) change drivers at local scale is vital for development of management strategies to tackle further decline of natural resources. In connection to this, a study was conducted in Dire Dawa administration, Ethiopia to investigate the drivers for change in land use land cover and its impact on above ground biomass and regenerations of woody plants. A total of 160 respondents were selected randomly to collect data on drivers of LULC change. A multistage stratified cluster sampling was used for above ground biomass assessment. Nine sample plots of $10 \mathrm{~m} \times 10 \mathrm{~m}$ size in each cluster and a total of 36 sample plots in all clusters were randomly established. In all sample plots, woody plants having $>5 \mathrm{~cm}$ diameter were measured for their diameter at breast height (DBH), and biomass estimated using allometric equation. The study revealed that, cutting of woody plants for fuel wood and making charcoal, population growth, expansion of cultivated land, drought, settlement areas and livestock ranching are the major six important drivers of LULC change. The study also revealed that, the mean above ground biomass of woody plants in Dire Dawa Administration was 4.94 ton/ha, with maximum and minimum above ground biomass of 6.27 ton/ha and 3.90 ton/ha, respectively. The number of regenerants of tree species was low and only $36 \%$ of the plots had tree regenerants. Thus, proper woodland management strategies implementation, land use planning, afforestation and reforestation activities are recommended to minimize unprecedented LULC change in the study area.
\end{abstract}

\section{Keywords}

Land Use Land Cove Change, Drivers, Above Ground Biomass, Regeneration 


\section{Introduction}

Land use and land cover change is widespread, accelerating, and significant processes driven by human actions but also producing changes that impact humans [1]. These changes alter the availability of different biophysical resources including soil, vegetation, water, animal feed and others. Consequently, land use and cover change could lead to a decreased availability of different products and services for human, livestock, agricultural production and damage to the environment as well.

Dependence on forest for energy, food, medicine and other products posed pressure on physical integrity, diversity and productivity of forests and woodlands. Furthermore, grazing, and subsistence agriculture have also created intense, competing demands on the vegetation cover. In Sub-Saharan Africa, changes in land cover are possibly driven by five categories of causes: long-term natural changes in climatic conditions; geomorphologic and ecological processes (e.g., soil erosion and natural vegetation dynamics); human-induced alterations of vegetation cover and landscapes (e.g., deforestation and land degradation); inter annual climatic variability (e.g., recurrent droughts and floods); and human-induced climatic changes [2].

In Ethiopia, steadily growing population pressure and agricultural expansion will inevitably increase the forest resources utilization (construction and fuelwood), and hence, different forms of unsustainable forest utilization will take place (fires, encroachment, logging, cultivation, urbanization) in coming decades ultimately leading to the total forest depletion. Based on the most recent estimates of the rates of deforestation, and assuming that 75 percent of forest losses are attributable to agricultural expansion, it is estimated that over the next 25 years the agriculture sector will require an additional 250 to 300 million hectares of new land to accommodate the demands of commercial farming, subsistence cropping, pasture and range development. Most of this increase in land will come at the expense of forests lands [3].

Similarly deforestation and forest degradation are serious environmental challenge in Ethiopia. Destruction of the natural forests of Ethiopia results directly in the loss of unaccounted plant and animal species as well as in a shortage of fuelwood, timber and other forest products. It also indirectly leads to more aggravated soil erosion, deterioration of the water quality, reduction of agricultural productivity, and to an ever-increasing poverty of the rural population [3]. It is obvious that the depletion of forest resources contributes significantly to the climatic and physical changes of the environment [4] [5].

Ethiopia's rural energy needs are predominately satisfied by biomass (>90\%). This includes traditional energy sources such as fuelwood, charcoal, and branches, leaves, and twigs. Authorised and unauthorised logging, however, is currently a relatively minor driver of forest degradation [3]. Currently forest and biodiversity degradation are attracting the attention of governments and the media [6] [7]. Additionally, drought and other natural phenomenon compli- 
cated the problem [8] [9] [10]. Hence, maintenance of plant species diversity in the understory should be an important goal of current silviculture prescriptions; not only because of their sensitivity to disturbance but also because of their essential role in ecosystem structure and function [11] [12].

Biomass is an important element in the carbon cycle, specifically carbon sequestration. It is used to help to quantify pools and fluxes of greenhouse gases (GHG) from the terrestrial biosphere to the atmosphere associated with land use land cover changes [13]. Changes in aboveground biomass were linked primarily with fire and harvesting. Fire was the most important single factor contributing for woodland degradation ( 50\%) compared with pole harvesting (12\%), charcoal production (10\%) and agriculture (31\%) [14]. At the more arid end of the spectrum, woody biomass is a key resource with respect to both ecosystem structure and functioning, as well as to rural communities, especially for fuelwood [15] [16].

It is so important to assess the land use land cover change drivers, vegetation composition and regeneration potential, and above ground woody biomass for better management of the remaining vegetation and design appropriate policies for conservation of woodlands of Dire Dawa Administration. The study aims to identify the major drivers of land use and land cover change and its impacts on above ground biomass and regenerations of woody plants at Dire Dawa administration, Ethiopia.

\section{Material and Methods}

\subsection{Description of the Study Sites}

The study was conducted in Dire Dawa administration, which is located at 515 $\mathrm{km}$ east of the capital, Addis Ababa. It lies with latitude and longitude of $9^{\circ} 36^{\prime} \mathrm{N}$ $41^{\circ} 52^{\prime} \mathrm{E}$ and $9^{\circ} 60^{\prime} \mathrm{N} 41^{\circ} 86^{\prime} \mathrm{E}$ coordinates. Dire Dawa has an average high and low temperature of $31.8^{\circ} \mathrm{C}$ and $17.9^{\circ} \mathrm{C}$, respectively. The annual average precipitation is $612 \mathrm{~mm}$. The administration is divided into four clusters and sub divided into 38 rural kebeles (the lowest administration unit) (Figure 1).

\subsection{Data Collection}

\subsubsection{Vegetation Data Collection}

A multistage stratified cluster sampling was used in the study. First the four clusters of the administration were purposively selected. Secondly, each cluster was grouped into homogenous groups based on the type of vegetation and their coverage. Thirdly sample kebeles were randomly selected from each homogenous group. Finally, after reconnaissance survey of the sample kebeles, actual sampling of vegetation was done based on homogeneity via preferential sampling method. In Each kebeles three sample plots of $10 \mathrm{~m} \times 10 \mathrm{~m}$ were established. Hence, 9 plots for each clusters and a total of 36 sample plots (4 cluster * 3 kebeles $* 3$ replications) from the four clusters were established. The diameter of individual trees was measured using Diameter tape and recorded for trees 


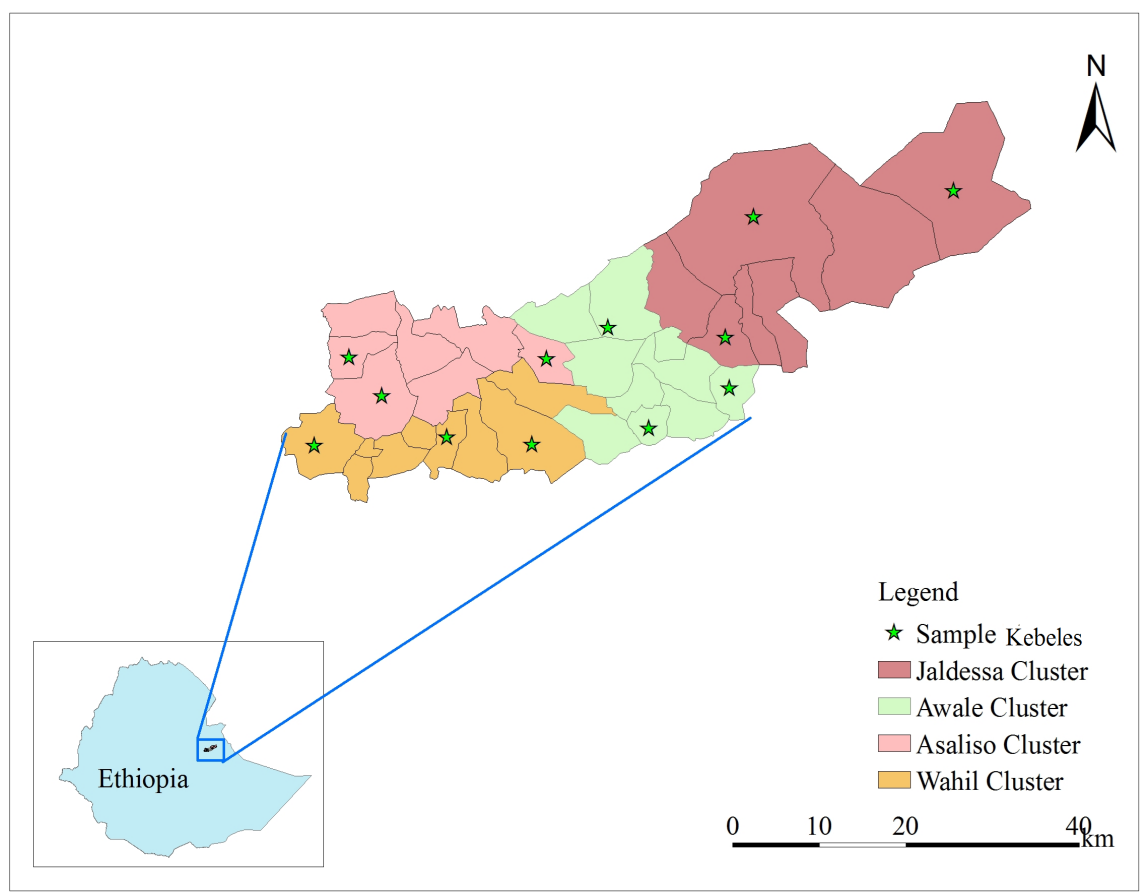

Figure 1. Map of the study area.

whose diameter at breast height $(\mathrm{DBH})$ is $>5 \mathrm{~cm}$. The DBH of irregular trees was measured using a method developed by [17]. Types of tree species, regeneration status and other physical features in the sample plots were also recorded.

\subsubsection{Sample Household Selection}

To collect data from farmers on the major drivers of land use land caver change of the Dire Dawa administration 40 respondents form each cluster were selected randomly. Accordingly, a total of 160 respondents were selected from the four clusters.

\subsubsection{Data Analysis}

For above ground biomass estimation, the equation developed by [18] for tropical dry forest was selected.

$$
Y=10^{\{-0.535+\log 10(B A)\}}
$$

where; $Y=$ biomass per tree in $\mathrm{kg}$, and $B A=$ basal area in $\mathrm{cm}^{2}$.

Basal diameter of a tree is an excellent predictor of dry weight. Further, fitted linear regression equations after log transformations were excellent predictors of biomass from stem diameters [19]. While, analysis of biomass and social data was done by using Statistical Package for Social Science (SPSS) software version 20 . Hence, one Way ANOVA was used at $95 \%$ confidence interval.

\section{Results}

\subsection{Drivers of LULC Changes in Dire Dawa Administration}

A total of six (6) major factors were perceived by the respondents as being important 
Table 1. Drivers of land use/land cover changes perceived by local people in Dire Dawa Administration study landscape.

\begin{tabular}{cccc}
\hline \multirow{2}{*}{ No. } & Drivers of LULC change & \multicolumn{2}{c}{ Farmers (Frequency) } \\
\cline { 3 - 4 } & & response & (Percent) \\
\hline $\mathbf{1}$ & Cutting of woody plants for fuel wood and making charcoal & 90 & 56.3 \\
2 & Population growth & 70 & 43.8 \\
$\mathbf{3}$ & Expansion of cultivated land & 65 & 40.6 \\
$\mathbf{4}$ & Drought & 45 & 28.1 \\
$\mathbf{5}$ & Housing (settlement) & 22 & 13.8 \\
$\mathbf{6}$ & Livestock ranching & 10 & 6.3 \\
\hline
\end{tabular}

Table 2. Clusters mean above ground woody biomass (ton/ha).

\begin{tabular}{|c|c|c|c|c|}
\hline \multirow{2}{*}{ Clusters } & \multicolumn{3}{|c|}{ Kebeles } & \multirow{2}{*}{$\begin{array}{l}\text { Total } \\
\text { Mean }\end{array}$} \\
\hline & 1 & 2 & 3 & \\
\hline Aseliso & $3.99 \pm 0.69$ & $4.36 \pm 2.09$ & $3.36 \pm 1.82$ & $3.90 \pm 1.50^{\mathrm{b}}$ \\
\hline Awale & $3.88 \pm 1.45$ & $5.60 \pm 0.58$ & $4.06 \pm 1.12$ & $4.51 \pm 1.26^{\mathrm{ab}}$ \\
\hline Jaldesa & $3.77 \pm 2.17$ & $4.39 \pm 1.12$ & $10.64 \pm 4.56$ & $6.27 \pm 4.19^{\mathrm{a}}$ \\
\hline Wahil & $5.13 \pm 1.11$ & $5.03 \pm 0.52$ & $5.05 \pm 0.73$ & $5.07 \pm 0.72^{\mathrm{ab}}$ \\
\hline LSD & & & & 2.25 \\
\hline
\end{tabular}

Means with the same letters are not significantly different at $\mathrm{P}=0.05$.

drivers of LULC changes in the study landscape (Table 1). However, there were variations about each of the factors to which the local people viewed as drivers for the LULC change. In particular, majority of the respondents $(n=160)$ perceived cutting of woody plants for fuel wood and making charcoal, population growth and expansion of cultivated land as the leading drivers of LULC changes. In addition, some of the respondents, i.e., 28.1, 13.8, and 6.3\% reported drought, housing (settlement), and livestock ranching, respectively, as also important causes for the observed LULC change in the study landscape. It was also understood from the account of the elder people during the focus group discussions that charcoaling is increasing over time in the study landscape.

\subsection{Estimated Woody Plants above Ground Biomass}

The mean above ground biomass of woody plants in Dire Dawa administration was 4.94 ton/ha (Table 2). The lowest mean above ground biomass was recorded in Aseliso cluster $(3.90 \pm 1.50)$ resulting from expansion of Dire Dawa town and exploitation of the vegetation for fuelwood both for own consumption and market by rural residents.

\subsection{Regeneration of Tree Species and Herbaceous Vegetation}

The number of regenerants of tree species in Dire Dawa administration was low (Figure 2). The poorly managed woodlands and forests are experienced human 


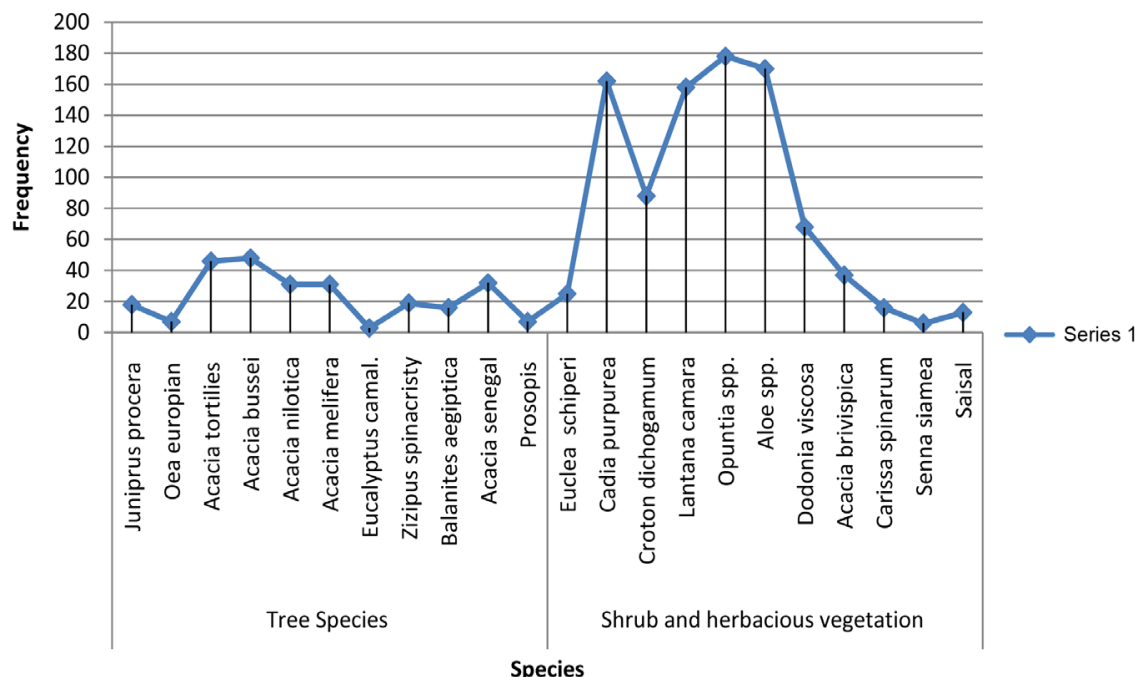

Figure 2. Tree and shrub and herbaceous regeneration in Dire Dawa Administration.

interference that leads to disturbance and fragmentation of the existing vegetation. Selective harvesting of some particular species such as Juniperus procera, Acacia tortiles, Acacia bussie and Acacia melifera, has affected species regeneration and diversity in the administration. It is well noted that disturbances are the primary causes of patchiness and heterogeneity in ecosystems.

\section{Discussions}

This results depicts that farmers ranking of all the perceived drivers of LULC change indicated that cutting of woody plants for fuel wood and making charcoal was ranked first and as the most influential driver followed by population growth, expansion of cultivated lands, drought, settlements, and livestock ranching (Table 1). It is, therefore, possible to conclude that anthropogenic factors are the driving forces for land use land cover change in Dire Dawa Administration. A study by [20] showed that human interference is the common factor affecting natural vegetation.

As indicated [21] annually Ethiopia losses about 150,000 to 200,000 ha of forest primarily for expansion of rain feed subsistence agriculture, fuelwood collection and over grazing. Also, the study of [22] on drivers of land use land cover changes in Munessa-Shashemene landscape of the south-central highlands of Ethiopia revealed that, all of the respondents perceived population growth and cultivated land expansion as the main drivers of LULC change; and the majority of the respondents reported settlement, fuelwood collection, and charcoal making as also important causes for the observed LULC changes in the study landscape.

This finding revealed that, cutting of woody plants for fuelwood and making charcoal was the primary important driver of the observed LULC change (Table 1). This is directly connected with the wide use of biomass based energy source in the country, particularly in the study areas [23] [24] [25]. Having the highest 
calorific value ( $\left.7800 \mathrm{Cal} \mathrm{g}^{-1}\right)$, acacia trees are preferred for charcoal making in Ethiopia [26]. This intensified the selective cuttings of the acacia-dominated woodlands that resulted in loss of the $95 \%$ of the coverage in the studied landscape in the last four decades [27]. Moreover, in the case of decline or failure of crop production due to decreasing rainfall, the local people are dependent on the sale of charcoal and fuel wood as an immediate source of income. Such coping strategies were practiced in other parts of the country [23] [24].

This finding also revealed that, the population increment and expansion of cultivated lands were other leading divers. There are Muslims in the study landscapes that still practice having more than two wives, which contributes for the population increment. At the same time, to support the rising population, there was a need for extensive agricultural production with continuous crop cultivation, which was the other driver of LULC change. This finding in line with the report by [28] who found that population growth and expansion of cultivated land were largely responsible for LULC changes in Northwest Ethiopia. Another studies in other parts of the country also reported population pressure and agricultural crops as major drivers of LULC changes [29] [30] [31] [32].

The mean above ground biomass of woody plants in Dire Dawa administration was 4.94 ton/ha (Table 2). Comparison of the mean above ground woody biomass of three kebeles from each cluster has shown that Jeldesa cluster has the highest above ground woody biomass $(6.27 \pm 4.19)$ compared with other clusters, which is attributed to the presence of well protected riparian forests and less exploited for fuelwood and construction as it is far from major cities and less populated pastoral area. The study of [5] revealed that there is less exploitation of forests for fuelwood and construction when the area far from major cities.

The number of regenerants of tree species in the forest was low and only $36 \%$ of the plots had tree regenerants. Similarly, 279 tree regenerants were recorded out of the total 1116 observation where the remaining (837) regenerants are herbaceous plants. The tree species with relatively higher number of regenerants were Acacia tortilies (46), Acacia bussie (48), Acacia Senegal (32), Acacia melifera (31) and Acacia nilotica (31). On the contrary herbaceous species such as Opuntia spp (178), Aloe spp. (170), Cadia purpurea (161) and Lantana camara (158) were found in abundant (Figure 2). The low number of tree regenerants is attributed to human activities such as fuelwood collection, charcoal making. Besids, the arid agro-ecology of the administration, limited germination and growth of seedlings [33] [34].

As noted by [30] maintenance of natural regeneration requires sustainable management of natural resources which demands integration of protective, productive, social and environmental aspects of natural resources. In all surveyed plots regeneration of shrub and herbaceous is higher than tree species, which indicates the severity of degradation of woodlands, natural and plantation forests. Furthermore, low regeneration of tree species will have negative impact on the future biomass of the administration. 


\section{Conclusions}

The assessment of LULC change drivers revealed that the changes occurred in the Dire Dawa Administration landscape due mainly to the interplay among more than 6 drivers related to social, economic, environmental, and technological factors. Specifically, cutting of woody plants for fuel wood and making charcoal, population growth, expansion of cultivated land, drought, settlement areas and livestock ranching are the major six important drivers of LULC changes as viewed by the local people as well as from the detailed quantitative landscape level analyses.

The findings further depicted that there was low woody plants above ground biomass and low regenerants of tree species, among the main threat to the physical integrity, biomass and regeneration of woodlands and forests of the Dire Dawa Administration, cutting of woody plants for fuel wood and making charcoal, population growth, expansion of cultivated land were the top major factors.

The mean above ground biomass of woody plants in Dire Dawa Administration was 4.94 ton/ha, with maximum and minimum above ground biomass of 6.27 ton/ha and 3.90 ton/ha, respectively. The number of regenerants of tree species was low and only $36 \%$ of the plots had tree regenerants. Thus, appropriate policy and strategy centered on those major drivers are urgently required in order to avert the ongoing undesirable LULC changes of resources in this important landscape of the Dire Dawa Administration. And proper cultivation of the land with appropriate implementation of soil fertility management measures and afforestation and reforestation activities are recommended.

\section{Acknowledgements}

This research was sponsored by Dire Dawa Administration Agriculture, Water, Energy and Mine bureau (AWEMB) through Haramaya University Community Engagement and Enterprise Development vice president office.

\section{References}

[1] Agarwal, C., Green, G.M., Grove, J.M., Evans, T.P., and Schweik, C.M. (2002) A Review and Assessment of Land-Use Change Models: Dynamics of Space, Time, and Human Choice. General Technical Report NE-297. U.S. Department of Agriculture, Forest Service, Northeastern Research Station, Newtown Square, 61. https://doi.org/10.2737/NE-GTR-297

[2] Lambin, E.F. and Ehrlich, D. (1997) Land-Cover Changes in Sub-Saharan Africa (1982-1991): Application of a Change Index Based on Remotely Sensed Surface Temperature and Vegetation Indices at a Continental Scale. Remote Sensing of Environment, 61, 181-200. https://doi.org/10.1016/S0034-4257(97)00001-1

[3] Mulugeta, L. and Zenebe, M. (2011) Combretum Terminalia Broad-Leaved Deciduous Forests. In: Kelbessa, E. and Girma, A., Eds., Forest Types in Ethiopia: Status, Potential Contribution, Challenges and Recommendation. Forum for Environment, Addis Ababa, 53-78.

[4] Bond, T.C., Zarzycki, C., Flanner, M.G. and Koch, D.M. (2011), Quantifying Immediate Radiative Forcing by Black Carbon and Organic Matter with the Specific Forcing Pulse, Atmos. Chemical Physics, 11, 1505-1525. 
https://doi.org/10.5194/acp-11-1505-2011

[5] Schultz, M. (2011) Land and Forest-Cover Change Analysis, Western Area Peninsula Forest Reserve (WAPFR), Sierra Leone. 2nd Report of Activities, OBf 2011.

[6] Singh, G.S., Rao, K.S. and Saxena, K.G. (1997) Energy and Economic Efficiency of the Mountain Farming System: A Case Study in the North-Western Himalaya. Journal of Sustainable Agriculture, 9, 25-49. https://doi.org/10.1300/J064v09n02_04

[7] Hegde, R. and Enters, T. (2000) Forest Products and Household Economy: A Case Study from Mudumalai Wildlife Sanctuary, Southern India. Environmental Conservation, 27, 110. https://doi.org/10.1017/S037689290000028X

[8] Pimm, S.L., Russell, G.J., Gittleman, J.L. and Brooks, T.M. (1995) The Future of Biodiversity. Science, 269, 347-350. https://doi.org/10.1126/science.269.5222.347

[9] Groombridge, B. (Ed.) (1992) Global Biodiversity: Status of the Earth's Living Resources. World Conservation, Monitoring Center. Chapman and Hall, London. https://doi.org/10.1007/978-94-011-2282-5

[10] Brook, B.W., Bradshaw, C.J.A., Koh, L.P. and Sodhi, N.S. (2006) Momentum Drives the Crash: Mass Extinction in the Tropics. Biotropica, 38, 302-305. https://doi.org/10.1111/j.1744-7429.2006.00141.x

[11] Maclean, D.A. and Wein, R.W. (1977) Changes in Understory Vegetation with Increasing Stand Age in New Brunswick Forests: Species Composition, Cover, Biomass and Nutrients. Canadian Journal of Botany, 55, 2818-2831.

https://doi.org/10.1139/b77-320

[12] Roberts, M.R. and Gilliam, F.S. (1995) Patterns and Mechanisms of Plant Diversity in Forested Ecosystems: Implications for Forest Management. Ecological Applications, 5, 969-977. https://doi.org/10.2307/2269348

[13] Cairns, M.A., Brown, S., Helmer, E.H. and Baumgardner, G. (2003) Root Biomass Allocation in the World's Upland Forests. Oecologia, 111, 1-11. https://doi.org/10.1007/s004420050201

[14] Chidumayo, E.N. (2013) Forest Degradation and Recovery in a Miombo Woodland Landscape in Zambia: 22 Years of Observations on Permanent Sample Plots. Forest Ecology and Management, 291, 154-161. https://doi.org/10.1016/j.foreco.2012.11.031

[15] Pandey, D. (2002) Fuelwood Studies in India: Myth and Reality. Center for International Forest Research, Bogor, 28-32.

[16] Shackleton, C.M. and Shackleton, S.E. (2004) The Use of Woodland Resources for Direct Household Provisioning. In: Lawes, M.J., Eeeley, H.C., Shackleton, C.M. and Geach, B.S., Eds., Indigenous Forests and Woodland in South Africa: Policy, People and Practice, University of KwaZulu-Natal Press, Pietermaritzburg, 195-226.

[17] Pearson, T.R., Brown, S.L. and Birdsey, R.A. (2007) Measurement Guidelines for the Sequestration of Forest Carbon. USDA Forest Service 19073-3294. https://doi.org/10.2737/NRS-GTR-18

[18] Martinez-Yrizar, A.J., Sarukhan, A., Perez-Jimenez, E., Rincon, J.M., Maass, A., Magallanes, S. and Cervantes, L. (1992) Above-Ground Phytomass of a Tropical Deciduous Forest on the Coast of Jalisco, Mexico. Journal of Tropical Ecology, 8, 87-96. https://doi.org/10.1017/S0266467400006131

[19] Okello, B.D., O’Connor, T.G. and Young, T.P. (2001) Growth, Biomass Estimates, and Charcoal Production of Acacia drepanolobium in Laikipia, Kenya. Forest Ecology and Management, 142, 143-153. https://doi.org/10.1016/S0378-1127(00)00346-7

[20] Grime, J.P. (1997) Biodiversity and Ecosystem Function: The Debate Deepens. 
Science, 277, 1260-1261. https://doi.org/10.1126/science.277.5330.1260

[21] EFAP (1994) Ethiopian Forestry Action Program. Ministry of Natural Resources and Environmental Protection, Addis Ababa.

[22] Mengistie, K., Thomas, S., Demel, T. and Thomas, K. (2015) Drivers of Land Use/Land Cover Changes in Munessa-Shashemene Landscape of the South-Central Highlands of Ethiopia. Environmental Monitoring and Assessment, 187, Article No. 452.

[23] Tegene, B. (2002) Land-Cover/Land-Use Changes in the Derekolli Catchment of the South Welo Zone of Amhara Region, Ethiopia. Eastern Africa Social Science Research Review, 18, 1-20. https://doi.org/10.1353/eas.2002.0005

[24] Teketay, D., Lemenih, M., Bekele, T., Yemshaw, Y., Feleke, S., Tadesse, W., Moges, Y., Hunde, T. and Nigussie, D. (2010) Forest Resources and Challenges of Sustainable Forest Management and Conservation in Ethiopia. In: Bongers, F. and Tennigkeit, T., Eds., Degraded Forests in Eastern Africa. Management and Restoration, Earthscan, London, Washington DC, 19-64.

[25] Asfaw, A. and Demissie, Y. (2012) Sustainable Household Energy for Addis Ababa, Ethiopia. Consilience: The Journal of Sustainable Development, 8, 1-11.

[26] Seboka, Y. (2008) Charcoal Supply Chain Study in Ethiopia. Proceedings of the Conference on Charcoal and Communities in Africa, Maputo, 16-18 June 2008, 53-61.

[27] Kindu, M., Schneider, T., Teketay, D. and Knoke, T. (2013) Land Use/Land Cover Change Analysis using Object-Based Classification Approach in Munessa-Shashemene Landscape of the Ethiopian Highlands. Remote Sensing, 5, 2411-2435. https://doi.org/10.3390/rs5052411

[28] Gashaw, T., Bantider, A. and Mahari, A. (2014) Population Dynamics and Land Use/Land Cover Changes in Dera District, Ethiopia. Global Journal of Biology Agriculture and Health Sciences, 3, 137-140.

[29] Bewket, W. (2002) Land Cover Dynamics since the 1950s in Chemoga Watershed, Blue Nile Basin, Ethiopia. Mountain Research and Development, 22, 263-269. https://doi.org/10.1659/0276-4741(2002)022[0263:LCDSTI]2.0.CO;2

[30] Hurni, H., Tato, K. and Zeleke, G. (2005) The Implications of Changes in Population, Land Use, and Land Management for Surface Runoff in the Upper Nile Basin Area of Ethiopia. Mountain Research and Development, 25, 147-154. https://doi.org/10.1659/0276-4741(2005)025[0147:TIOCIP]2.0.CO;2

[31] Dessie, G. and Kleman, J. (2007) Pattern and Magnitude of Deforestation in the South Central Rift Valley Region of Ethiopia. Mountain Research and Development, 27, 162-168. https://doi.org/10.1659/mrd.0730

[32] Kidane, Y., Stahlmann, R. and Beierkuhnlein, C. (2012) Vegetation Dynamics, and Land Use and Land Cover Change in the Bale Mountains, Ethiopia. Environmental Monitoring and Assessment, 184, 7473-7489. https://doi.org/10.1007/s10661-011-2514-8

[33] Sheppard, A.W., Hodge, P., Paynter, Q. and Rees, M. (2002) Factors Affecting Invasion and Persistence of Broom Cytisus scoparius in Australia. Journal of Applied Ecology, 39, 721-734. https://doi.org/10.1046/j.1365-2664.2002.00750.x

[34] Strand, M., Ottosson, L.M., Bergsten, U., Lundmark, T. and Rosvall, O. (2006) Height Growth of Planted Conifer Seedlings in Relation to Solar Radiation and Position in Scots Pine Shelterwood. Forest Ecology and Management, 224, 258-265. https://doi.org/10.1016/j.foreco.2005.12.038 